\title{
Philippines: Report on the Observance of Standards and Codes- Fiscal Transparency Module-Update
}

This update to Report on the Observance of Standards and Codes-Fiscal Transparency Module for the Philippines was prepared by a staff team of the International Monetary Fund as background documentation for the periodic consultation with the member country. It is based on the information available at the time it was completed on February 20, 2004. The views expressed in this document are those of the staff team and do not necessary reflect the views of the government of the Philippines or the Executive Board of the IMF.

The policy of publication of staff reports and other documents by the IMF allows for the deletion of market-sensitive information.

To assist the IMF in evaluating the publication policy, reader comments are invited and may be sent by e-mail to publicationpolicy@imf.org.

Copies of this report are available to the public from

International Monetary Fund $\bullet$ Publication Services

700 19th Street, N.W. • Washington, D.C. 20431

Telephone: (202) 6237430 • Telefax: (202) 6237201

E-mail: publications@imf.org • Internet: http://www.imf.org

\section{International Monetary Fund Washington, D.C.}



INTERNATIONAL MONETARY FUND

\section{PHILIPPINES}

\section{Report on the Observance of Standards and Codes (ROSC)} Fiscal Transparency Module-Update

Prepared by the Asia and Pacific Department

Approved by Masahiko Takeda

February 20, 2004

This ROSC update has been prepared in the context of the 2003 Article IV consultation with the IMF and reflects comments by the authorities. 


\section{INTRODUCTION}

The original fiscal ROSC was issued in October 2002. During the 2003 Article IV consultation, IMF staff reviewed developments in the areas pertaining to the Philippines' observance of the fiscal transparency practices assessed in 2002, with a view to updating, where relevant, changes in current practices or describing the implementation of the earlier ROSC's recommendations. Unless indicated differently below, the recommendations made in the 2002 ROSC remain relevant.

\section{Description of Progress}

Staff recommendations in the original ROSC focused on four main areas. Developments in each of these areas include the following:

Clarity of roles and responsibilities. The clear separation of fiscal and public enterprise management has been reduced somewhat by the rising losses of the National Power Corporation (NPC), which have been funded in part by the purchase of NPC-issued bonds by the national government (approximately P 40 billion in 2003) and shown as investments below the line. While NPC losses are fully captured in the consolidated public sector deficit, this onlending has resulted in an inconsistent presentation of onlending in the national government accounts, as onlending to the NPC is shown below the line, while other net lending is shown above the line.

Public availability of information. The decline in the ratio of revenue to GDP in recent years continues to highlight the need for more published information on special tax incentives provided to the private sector, particularly with regard to the fiscal costs.

Open budget preparation, execution, and reporting. A new procurement law was signed in January 2003, for which implementing regulations took effect in October 2003. Key reforms in the new law and regulations include the following:

- $\quad$ The law requires all agencies to hook up to a central internet portal that will be the definitive source of information on all government procurement, including a Public Tender Board for posting procurement opportunities, notices, awards, and reasons for award; an Electronic Catalog, to support purchases of goods and services; and a Supplier Registry, which is an electronic database of all manufacturers, suppliers, distributors, contractors, and consultants registered under the system.

- $\quad$ Previously, a lengthy prequalification process was undertaken. However, this has been noted to result in the subjective and nontransparent favoring of certain bidders. Under the new law, a simplified pass/fail eligibility check is coupled with a thorough post-qualification check for winning bidders in order to reduce administrative costs and opportunities for corruption. 
- The law reduces agencies' discretion in choosing among bidders because contracts are awarded on criteria in the bid documents that are more objective criteria than before. For goods and infrastructure projects, because minimum specifications are provided for in the bid documents, the criteria for awarding contracts have been simplified to the lowest bid.

- $\quad$ The law eliminates the establishment of floor prices for bids, which previously created an opportunity for collusion between agencies and bidders and limited the government's potential savings from low bids.

- $\quad$ The law and regulations also improve transparency through introducing standardized procurement forms, allowing NGOs to observe procurement proceedings, and raising penalties for corruption.

Many of these reforms had already been implemented administratively; however, the law codified them into a single law that is now also valid for local government units and the armed forces.

Progress has also been made in linking the obligation control system to available cash. In 2003, this was facilitated by limiting allotment releases at the start of the year to only 50 percent of the full-year appropriations. As a result, the authorities had more flexibility to adjust spending to revenue and financing developments that occurred during the year. The monitoring of available cash should be further enhanced by the recently established online viewing by the Department of Budget and Management of government bank balances with the Land Bank of the Philippines, which accounts for at least 90 percent of total accounts under the modified disbursements system, and the Electronic Linkage Project, which is in the pilot stage and will link the databases of the treasury with key revenue and spending agencies to facilitate the transmission of daily cash collection and disbursement reports.

Progress has also been made in implementing the New Government Accounting System (NGAS, a modified accrual-based system). The FY2002 Annual Financial Reports for national and local governments that were submitted to congress in September 2003 were the first such reports based on NGAS. The implementation of NGAS for government corporations is to begin in 2004, and training on NGAS has been conducted continuously.

There has been some strengthening of internal audit control systems, with an administrative order in April 2003 requiring all government offices, local government units, and government corporations to organize an internal audit service in their respective organizations. Notably, the Department of Finance is investigating many tax and customs officials for allegations of graft and has filed charges against several staff.

Finally, revenue estimates have become somewhat more realistic, with the tax revenue outturn in 2003 being only 1 percent different than the official projection.

Independent assurances of integrity. There have been no major developments in this area. 


\section{IMF STAFF COMMENTARY}

Staff welcome the recent improvements in procurement rules, cash management, accounting systems, internal audit, and revenue projections. The procurement reforms, in particular, are a significant achievement. While it is still too early to judge the magnitude of the impact, including on corruption, staff hope that the dividends will be substantial, both in terms of expenditure savings and improved governance.

Nonetheless, a large number of recommendations from the 2002 ROSC on fiscal transparency remain to be implemented, particularly those in the areas of quality, timeliness, and comprehensiveness of published data, consolidation and modernization of the organic budget law, and independent assurances of data integrity. Staff continue to believe that improvements in these areas would significantly enhance fiscal management and transparency. 